\title{
esCALATION CLAUSES IN GAS PURCHASE CONTRACTS
}

\section{MILTON TAYLOR*}

Prior to World War II, no one deliberately looked for natural gas. In fact, gas was considered to be a nuisance. However, with the tremendous growth in markets throughout the world since the war, the gas industry has grown to be the fifth largest industry in the United States. But it is not an undivided industry, and as Gregg says

Like Ancient Gaul, however, it is divided into three parts: the producers, the transmission or transportation companies, and the distributors, each vying strenuously with each other; and it has become embroiled in a gigantic experiment manipulated by politicians, state regulatory agencies, the Federal Power Commission, and the federal courts. To add to its difficulties, it is beset also by the representatives of competing fuels.'

That there is competition between competing agencies within the industry is reflected in the terms of the gas purchase contracts. Pipeline buyers need the certainty of long-term gas supplies; gas producers, on the other hand, find their interest in avoiding firm price commitments, especially when they have reason to expect a rising level of field prices. The practical resolution of this conflict, in the course of purchase contract negotiations, has undoubtedly fostered many of the present field market practices. On the whole, these practices favor the gas producer who gains an assured market while retaining the possibility of a benefit from rising field prices.

With the increased demand during the post-war years, one of the most notable changes in gas purchase contracts has been the lengthening of the contract term. Twenty-year terms are now common, and in many cases the contract remains in force throughout the producing life of the gas field. To this emphasis on long-term agreements, which was necessary for the financing of pipelines, the producer has reacted as best he has been able through price negotiation. The scope of this article is limited to a discussion of the escalation clauses which have resulted from these price negotiations. Gregg suggests that the price provisions are the most important provisions in any gas contract:

The producer was and still is placed in an extremely difficult position. Faced with rising costs, a long-term inflationary trend in finding new reserves on the one hand, and the requirement that he sell his gas on a long-term basis under a contract which is subject to abrogation by the regulatory process, he has done the only thing which he could do and devised safeguards for his property through the price provisions of his contracts."

The provisions may be divided into two basic types: first, one finds "fixed" escalations of prices or specific price increases during the term of the contract, and second, one finds "indefinite" escalations of prices during the contract term. The advantages of the "fixed" price escalations are not readily obvious. They do have the effect of providing the pipelines with a greater degree of profit during the formative years of their development, but total revenues would be the same (as would

- M.A. (Brigham Young); LL.B. (Alta.), of the Graduating Class of 18G4, University of Alberta.

1 Gregg. Negotiating and Drafting Ges Purchase Contracts on Behalf of Seller, Thirteenth Annual Instltute On OIl and Gas $L_{\text {aw }}$ and Taxation, at 87, (1962), hereafter referred to as "Gregs".

2 Gress, at 127. 
total expenses) under a contract of a fixed price throughout the contract period, if such price was the average of the escalation price. However, if under the fixed escalation price clause the initial price equals the presently prevailing price, then it is obvious that these escalations represent a strengthening seller position in the market.

All contracts must fix an initial price for the product purchased and sold, or else provide a method for determining such initial price. ${ }^{3}$ It is in addition to this fundamental requirement of all contracts that one finds the clauses with which we are presently concerned. Richardson says that "the real meat in the gas sales coconut, and the most fruitful source of controversy", are found in the pricing provisions." His discussion of the various clauses emphasizes the high degree of control the Federal Power Commission has exercised in the United States. The Commission has jurisdiction over the transportation of natural gas in interstate commerce, its sale in interstate commerce for resale, and over natural gas companies engaged in such transportation or sale. ${ }^{b}$ The Commission exercises its authority over such natural gas companies, inter alia, by investigation and review of rates.

The most common escalation clauses fall within the following general categories:

\section{Favored-Nation Clause.}

This clause may be either the "two-party" favored-nation clause or the "third-party" favored-nation clause. Under the two-party favorednation clause, the buyer is obligated to increase the price that he pays for gas under the contract to equal the price which he pays any other producer within a specified or described area. The third-party favorednation clause obligates the buyer to increase the price which the buyer pays for gas under the contract to equal the price which any other buyer pays for gas within a specified or described area. ${ }^{\circ}$

The result of the operation of these clauses has been to bring an upward adjustment in purchase contract prices. Obviously, the buyer has much greater control under the two-party favored-nation clause. Some contracts give the buyer the right to terminate the contract if the clause is brought into operation. These clauses have the effect first, of equalizing the bargaining positions of different sellers and second, of enabling sellers to obtain in otherwise firm agreements, some upward adjustment of prices to reflect price levels which may prevail in the future. Howell says that during many contract negotiations the parties have reached an impasse when negotiating the price to be paid for future deliveries. This "most-favored-nation" clause was devised to bridge this impasse. ${ }^{7}$

\section{Bona Fide Offer Provision.}

This clause requires the buyer to meet any bona fide offer made to the seller at an increased price, for the gas being sold under the contract,

3 Willams, Oil and Gas Law, s. 725.1, p. 739, (1959) hereafter referred to as "Willams".

- Richardson. Producer Contracts For Sale of Natural Gas in Interstate Commerce, Eleventh Annual Institute On Oil and Gas Law and Taxation, 201, 223, (1960).

5 Id. at 203.

- Gregs, 133. Examples of the various price provision clauses commonly included in the sas purchase contract are found in Willams, 704, 763.

7 Howell, Gas Purchase Contracts, Fourth Annual Instltute On Oll and Gas Law and Taxation, 151, 175, (1953). 
with the seller often given the right to terminate sales under the contract should the buyer fail to meet a bona fide offer at a higher price. ${ }^{8}$

\section{Renegotiation, Redetermination, Or Better-market Clause.}

Hereunder, periodically or at stated intervals, the contract price may be renegotiated with a provision for arbitration in case the parties fail to reach an agreement. ${ }^{83}$ Such clauses usually give some standard for arbitration, such as an average of a fixed number of the highest prices being paid within a prescribed area for comparable gas. ${ }^{\circ}$ This is one more means of providing price flexibility. Sellers are provided with assurance of upward price adjustments over reasonably short periods to levels reflecting current field prices.

\section{Spiral Escalation Clause.}

The price to be paid is automatically increased upon the happening of certain events, such as rate increases which may be secured by the buyer. ${ }^{10}$ Although this might be considered as a clause to counteract inflation, it is possible for prices to rise even during a recession, depending upon the base used.

\section{Periodic or Step-Price Increase Clause.}

This clause provides for periodic increases in the price to be paid. For example, such a clause might provide for an increase of 1 cent per million cubic feet at the end of each five year period."1

\section{Tax Increase Clause.}

The usual provision obligates the buyer to reimburse the seller for all or some specified portion of new or increased production, severence, gathering, or similar taxes in addition to or greater than those in effect at the inception of the contract and which the seller pays either for himself or on behalf of others, including royalty holders. ${ }^{12}$ The purpose of these clauses, from the seller's point of view, is to avoid the revenue loss which might result if tax levies are increased after a contract with firm prices has been negotiated.

\section{BTU Adjustment Clause.}

The price to be paid for gas or casing head gas may be adjusted upward or downward in the event of variation in the heating quality of the gas supplied. ${ }^{28}$

\section{Commodity Price Index Clause.}

This clause provides for price adjustments to be made in accordance with the movement of commodity prices in a certain specified index, such as the Index of Wholesale Prices of All Commodities." ${ }^{14}$ It serves to protect producers from the effects of inflation. Often this allows price decreases as well as price increases, but there is generally a stipulation that such decreases shall not fall below the initial price.

8 Wllltams, 8. 726 at pp. $751-752$.

84 COn the necessity for the arbltration clause, see May \& Butcher V. R. (H.L. (E.) 1929) (1934) 2 K.B. 17n.: Hillas \& Co. v. Arcos Ltd. (H.L. (E) 1932) 36 Com. Cas. 353,38 Com. [193. 23; Poley v. Classique Coaches Ltd. (C.A.) [1934] 2 K.B. 1: Calvan Consol. Oil \& Gas Cas. 23; Poley v. Classique Coaches Ltd.

o Willaims, at 752 .

10 Id. at 755 .

11 Jd. at 758 . 138

13 Willams, 8.726 at p. 761.

14 Greag, 135 - 186. 
The reaction to these "indefinite" clauses has been varied. Williams suggests that such clauses themselves are distinctly out of favor with the Federal Power Commission. The Commission has now passed Regulations providing for (i) the rejection of contracts containing indefinite escalation clauses, (ii) the rejection of applications by producers for certificates of public convenience and necessity relying for a gas supply upon contracts containing such indefinite escalation clauses and (iii) the Commission's refusal to consider such contracts submitted in support of certificate applications by pipeline companies. ${ }^{10}$ It is not within the scope of this paper to trace the reaction of the Federal Power Commission to the escalation clauses, and reference has been made to the Commission for two reasons: first, to indicate the reaction in another jurisdiction which has been faced with various problems that may arise in Alberta, and second, because of the lack of available material in our own jurisdiction. But this does not mean that Alberta should adopt the policies of the Commission, especially since the view of the Commission has not been universally accepted. Gregg, for instance, says:

In spite of the criticism of price escalation clauses, there is nothing intrinsically wrong with them. Natural gas is the only commodity which is bought and sold under contracts of such duration. These clauses are designed to give the producer the market value of his gas production over the life of the contract. They are helpful to the pipeline purchaser and the consumer in that instead of averaging the fixed escalations over the life of the contract and specifying one price in the instrument, advantage is taken of the lower prices at the outset of the contract term with the increases occurring after the pipeline has established its business and presumably reduced its long-term debt. ${ }^{20}$

It has already been suggested that these clauses have been the result of necessity. It is submitted that this necessity provides at least one reason why their validity should not be destroyed by legislation.

According to W. T. Sage, ${ }^{37}$ there has been no interference in Alberta with the purchase contracts in relation to the various escalation clauses. However, The Gas Utilities Act ${ }^{18}$ is certainly broad enough that the Gas Utilities Board could interfere. Under the definition section, "gas utility" includes the production machinery. Under Part I of the Act, the Board, upon an order of the Lieutenant Governor in Council, may fix and determine a "just and reasonable price for gas". The escalation clauses have a direct price relationship, and therefore it is submitted that escalation clauses could also be affected by the Board. Likewise, in Part II, the Board is given an element of control over contracts. It is conceivable that in the future the Board may take steps similar to those taken by the Federal Power Commission. Perhaps, however, the mere threat of such action will provide incentive for the gas producers to maintain fair and reasonable prices without such action.

It was argued recently before the Appellate Division of the Supreme Court of Alberta that such clauses as the favored-nation clause are void for uncertainty. In Permo Gas \& Oil Ltd. v. Pacific Petroleums Ltd.19

\footnotetext{
16 Willams, s. 728.1 at p. 769.

10 Gresg, $90-91$

17 Thls Information was given at an Intervlew on December 9, 1963 in Edmonton. $W . T$. Sage is Assistant Division Production Superintendent For Gas, for Imperial oll Company. Note: Calgary \& Edmonton Corp. v. B.A. Oil Co., (S.C. Alta. 1963) 41 W.W.R. 413 , held that the Public Utilities Boand has no power to interpret contracts and so settle disputes between contracting partles-this is for the courts.

18 (Allo.) 1960, c. 37.

1040 D.L.R. (2d) 109.
} 
an agreement for the sale and purchase of natural gas produced from certain lands provided that if the buyer,

shall enter into any contracts for the purchase of gas with any producer ... upon terms more favorable to such producer ... than the terms thereof. Seller shall have the right ... to have this contract modified (accordingly).

In answer to the argument that such contract was void for uncertainty because it might often be difficult to assess the various terms of an agreement to determine that "the terms" of one agreement were in fact more favorable, Johnson J.A. said:

I feel the fallacy of such reasoning should be pointed out. The clause itself is clear enough. If the weighing of the advantages and disadvantages of the 'terms' of one agreement over the other agreement is difficult, that cannot change the meaning of the clause. In a practical way no real difficulty need be anticipated. He who seeks to adopt 'terms' which he considers 'more favorable' must satisfy the Court that they are in fact just that. The appellant in this case, has not satisfied this burden.20

Thus the validity of the favored-nation clause has been sustained in Alberta. Such clauses are common in gas purchase contracts and therefore one needs but reflect a moment to realize the disrupting consequences that a negative decision would have had upon the contracts which are operative at the present time.

Neuner suggests that the two major changes in the postwar history of natural gas field markets in the Southwest are the drastic price changes, and the change in contract flexibility, in the form of a gradual ascendancy of those contract combinations most advantageous to gas producers. $^{21}$ He has developed a tabulation of combinations encountered in the purchase contract and arranged this information in order from the greatest to the least seller advantage. ${ }^{22}$ It is submitted that an examination of gas purchase contracts in Alberta indicates that a similar trend has taken place in reference to the escalation clauses, and the rise in Alberta price levels is obvious.

Some of these contract provisions are considered as devices leading to excessive field price increases. These provisions have (by implication) been viewed as monopolistic practices. Neuner states:

Generally speaking, such contract provisions have one common feature, which is pertinent at this point; they make possible price changes in what are otherwise long-term gas supply arrangements. However, effectiveness in this connection differs markedly. Tax-sharing and fixed price escalation permit only relatively small price changes, while two-party favored nation clauses make contract price changes discretionary with the buyer. Only price redetermination clnuses or third-party favored nation clauses give any large measure of contract price flexibility. ${ }^{23}$

20 Id. at 114. [Cr. n. 8a supra-Bd.]

21 Neuner, The Natural Gas Industry 111. (1960).

22 Id. at 110. Following is a reproduction of Neuner's tabulation of comblnations.

1. 20 year contract; third-party favored nation: mult1-distrlct favored natlon area.

2. 20 year contract; third-party favored nation; single district favored nation area.

3. 20 year contract: two-party favored nation; 5 year price redetermination at average of 3 highest prices.

4. 20 year contract, no lavored nation; 5 year price redetermination with arbltration.

5. 5 year contract; no favored nation; 10 year price redetermination.

6. 20 year contract; no favored natlon; 10 year price redelermination.

7. 10 year contract; no lavored nation; no prlce redetermination.

8. 20 year contract; two-party nation; (favored) 15 year price redeterintnation; price-

index inflation clause.

9. Index Inflation clause. redetermination.

10. 20 year contract; two-party favored nation; narrow lavored nation area; no price redetermination.

11. 20 year contract; time-limited, two-party favored nation; no price redetermination. 12. 20 year contract; no favored nation; no price redetermination.

23 Id. at 264. 
He says that the three market practices which have the greatest relevance to the question of competition in the gas field include the favored nation device, the price redetermination stipulation, and the long-term purchase contract which ties buyer and seller together to prevent reallocation of committed gas supplies."

It was suggested above that the main presssure for long-term gas contracts has come, not from the producer, but from the pipeline operators, and in spite of the likelihood of increase in gas contract prices. Furthermore, it has been pointed out that such clauses have been included as a matter of necessity, and thus they are not inconsistent with independent seller action.

In assessing the argument that pricing practices are monopolistic, two tests have been applied. One test has been to determine whether a similar price structure would likely have developed even without the co-operation of sellers with each other. In other words, does the industry itself have characteristics which would have caused such practices in a more competitive situation? The second test has been to determine whether or not the pricing practices are so widely and uniformly followed that monopolistic seller practices may be inferred.2s

It is submitted that it is the nature of the industry itself which has caused these pricing practices. It has been the basic need of the pipelines for the long-term contract that has resulted in the basic need of the producers for price flexibility. Such would have been the situation even under more competitive producer circumstances. Furthermore, the long-term contract has been the result of transportation pressures, not producer pressures. Thus one cannot conclude that the gas purchase agreements have resulted from monopolistic market practices. Neuner states:

But to establish these possibilities as facts, requires something more than reference to the prevalence of these practices, since their prevalence cannot be considered any more evidence of monopolistic behaviour than the prevalence of a given price.20

The mere fact that such clauses are widespread does not indicate monopolistic practices, because these clauses are beneficial to sellers and so would be sought by them without collusion. Neuner suggests that there is not sufficient evidence to support an inference of seller collusion.

As to the second test of monopolistic price control, one considers uniformity, not prevalence. An examination of various contracts indicates there is not uniformity in the clauses. Only if such provisions were highly uniform in form and content might a monopolistic condition be inferred. There may be some degree of uniformity in the favorednation clause within the individual supply areas, but there is nothing within the favored-nation device which allocates markets among producers, as one would expect under a monopoly. It must be admitted, however, that within the individual supply area the favored-nation clause does have a monopolistic effect, but the buyer is able to venture out of the supply area, thus vastly limiting such effect.

\footnotetext{
24 Id. at 265.

25 Ibld. [Ce. Markham. An Alternative Approach to the Concept of Workable Competition, [1950] Am. Econ. Rev. 349-Ed.]

28 Id. at 267.
} 
Neuner concludes by saying that all lines of analysis lead to the conclusion that seller behavior is not monopolistic. He states:

A claim that prevalence of certain market practices was due entirely to monopolistic seller market power requires proof that they could not have been expected to develop as a result of independent soller action. Actually, the analyzed purchase contract data demonstrates quile clcarly that these practices could easily have been responses to conditions which are characteristic of gas field markets ... Had collusive monopoly been responsible for these market practices, introduction would have occurred earlier, over a shorter period of time, and in forms which from the beginning would have been more protective of seller interests. ${ }^{27}$

There is a danger that excessive use and application of the escalation clauses may cause an increase in prices at a higher rate than prevails in the economy as a whole. Perhaps if this situation results, there will be some reason for use of government regulatory process, as has been found necessary in the United States. Surely a better solution is that the gas producers, and indeed, the industry as a whole, assume the responsibility for seeing that the industry remains in balance with the economy as a whole. 